\title{
Special Topic Issue-Cereal Processing Crops of History, Seeds of Destiny
}

DOI:

$10.1205 / 096030803322437910$

Link to publication record in Manchester Research Explorer

\section{Citation for published version (APA):}

Campbell, G. (2003). Special Topic Issue-Cereal Processing Crops of History, Seeds of Destiny. Food and Bioproducts Processing: Transactions of the Institution of of Chemical Engineers, Part C, 81(3), 157. https://doi.org/10.1205/096030803322437910

\section{Published in:}

Food and Bioproducts Processing: Transactions of the Institution of of Chemical Engineers, Part C

\section{Citing this paper}

Please note that where the full-text provided on Manchester Research Explorer is the Author Accepted Manuscript or Proof version this may differ from the final Published version. If citing, it is advised that you check and use the publisher's definitive version.

\section{General rights}

Copyright and moral rights for the publications made accessible in the Research Explorer are retained by the authors and/or other copyright owners and it is a condition of accessing publications that users recognise and abide by the legal requirements associated with these rights.

\section{Takedown policy}

If you believe that this document breaches copyright please refer to the University of Manchester's Takedown Procedures [http://man.ac.uk/04Y6Bo] or contact uml.scholarlycommunications@manchester.ac.uk providing relevant details, so we can investigate your claim.

\section{OPEN ACCESS}




\section{EDITORIAL}

\section{Special Topic Issue-Cereal Processing Crops of History, Seeds of Destiny}

\begin{abstract}
"Cast your bread upon the waters, for after many days you will find it again... Sow your seed in the morning, and at evening let not your hands be idle, for you do not know which will succeed, whether this or that, or whether both will do equally well."
\end{abstract}

Ecclesiastes 11:1,6

Cereals feed the world and are the basis of civilization. More than $50 \%$ of what we eat, worldwide, comes directly or indirectly from cereals. Historically, the capacity of cereals to support large populations, combined with the requirement for settled existence to tend the land, encouraged the development of cities and hence states and nations. Many technologies and innovations widely used throughout the processing industries today were originally stimulated by the challenges of cereals. The morphological difference between wheat and rice, that the former has a crease in which the outer bran folds into the centre of the grain, while the latter does not, demanded radically different processing technologies that then profoundly influenced the respective technological development of East and West. Maintaining the wheat supplies shaped the organizational and military development of the Greek and Roman empires; Socrates advised, 'No man qualifies as a statesman who is entirely ignorant of the problems of wheat'. Cereal production, trade and processing are still major economic activities in every nation, and no food or bio-process engineer should be entirely ignorant of the importance and challenges of dealing with cereals.

Despite their incomparable role in underpinning the global food industry, ironically, cereals in their natural form are neither appetizing nor nutritious for humans. The desiccated kernels of wheat, maize and rice (the big three cereals) facilitate handling and long term storage, but are not palatable, while the starch molecules that store energy for the growing plant are poorly digestible by humans. Extracting and delivering the nutritional benefit of cereals therefore requires extensive and creative processing. Cereal processing usually starts with wet or dry milling to separate the nutritious starchy endosperm from the outer layer of protective bran. This primary processing yields products such as flour that are still unappetizing and indigestible and which must undergo yet further processing to gelatinize the starch and to develop attractive food products with acceptable and appealing flavours and textures. Cereal-based foods are widely acknowledged as the foundation of a healthy diet; however, food only contributes to a healthy diet if it is actually consumed, and it is the processing of cereals that renders them in forms tempting to consumers. Cereal processing is thus the key to promoting healthy eating.

Man does not live by bread alone, however, and the global population demands many non-food goods and materials by which to enjoy modern lifestyles. The chemical processing industries have enabled and delivered many such products and the enhanced quality of life that accompanies them, but at the cost of rapid depletion of finite resources and pollution of the biosphere. The processing industries of the future will inevitably require renewable resources (and benign technologies), and cereals are the most promising hope to meet this need. In the 21 st century, the discipline of cereal process engineering will become as commonplace and acceptable as petroleum engineering was in the 20th century, but will be carried out with a wistful backward glance at the short-sighted hubris of the past. Cereal scientists sometimes overlook the process engineering inherent in exploiting cereals; process engineers would be equally unwise to overlook cereals as one of the world's most important and versatile raw materials.

This Cereal Processing special topic issue highlights some of the current research activities around the world in primary and secondary processing of cereals for both food and non-food uses. It includes a paper on rice moisture measurement, papers on flour milling and breadmaking, the major primary and secondary cereal processes, respectively, and a paper detailing the opportunities and practicalities of processing cereals for non-food uses using fermentation technology. The engineering within cereals processing is clearly evident in these papers, as is the intellectual challenge in understanding, exploiting and transforming cereals effectively, imaginatively and economically.

Cereals were accorded divine status in both Greek and Roman religions. Our modern, distracted society occasionally overlooks the sanctity of cereals, but does so unwisely.

Dr Grant Campbell Satake Centre for Grain Process Engineering Department of Chemical Engineering, UMIST Subject Editor-Cereal Processing 